\title{
Termiticidal Activity of Libidibia ferrea var. ferrea and of the Association With Isaria spp. Against Nasutitermes corniger
}

\author{
Rosineide S. Lopes ${ }^{1}$, Mônica Cristina B. Martins ${ }^{2}$, Luciana G. de Oliveira ${ }^{1}$, Antonio F. da Costa ${ }^{1}$, \\ Venézio F. dos Santos ${ }^{1}$, Maria Tereza S. Correia ${ }^{2}$, Nicácio H. da Silva ${ }^{2}$, Auristela C. de Albuquerque ${ }^{3}$, \\ Elza Áurea Luna-Alves Lima ${ }^{4} \&$ Vera Lúcia M. Lima \\ ${ }^{1}$ Agronomic Institute of Pernambuco, Recife, PE, Brazil \\ ${ }^{2}$ Department of Biochemistry, Federal University of Pernambuco, Recife, PE, Brazil \\ ${ }^{3}$ Department of Biology, Federal Rural University of Pernambuco, Recife, PE, Brazil \\ ${ }^{4}$ Department of Mycology, Federal University of Pernambuco, Recife, PE, Brazil \\ Correspondence: Vera Lúcia M. Lima, Departamento de Bioquímica, Universidade Federal de Pernambuco, Av. \\ Prof. Moraes Rego, s/n, Cidade Universitária, Recife, PE, CEP: 50670-420, Brazil. Tel: 55-(81)-2126-8576. \\ E-mail: lima.vera.ufpe@gmail.com
}

Received: May 27, 2019

doi:10.5539/jas.v12n1p159
Accepted: October 2, 2019 Online Published: December 15, 2019

URL: https://doi.org/10.5539/jas.v12n1p159

The research is financed by Fundação de Amparo à Ciência e Tecnologia do Estado de Pernambuco (FACEPE), National Council for Scientific and Technological Development (CNPq), Coordination for the Improvement of Higher Level or Education Personnel (CAPES), and Banco do Nordeste do Brasil (BNB).

\begin{abstract}
Nasutitermes corniger (Motschulsky) is an urban termite pest that is controlled by chemical applications. We investigated the effect of the association of Isaria farinosa (Holm: Fries) Fries, I. fumosorosea (Wize) Brown \& Smith, and I. javanica (Frieder \& Bally) Samson \& Hywell-Jones with the extracts of Libidibia ferrea var. ferrea (Mart. Ex Tul.) L. P. Queiroz in the control of $N$. corniger. The following experiments were performed: the toxicity of aqueous and methanolic extracts on the biological aspects of fungi, action of extracts on workers and soldiers, and fungus-extract combination on workers of termite. The aqueous extracts of the leaves and pods of $L$. ferrea var. ferrrea were more efficient than the methanol extracts, demonstrating termiticide activity at 10, 25, 50, 100 , and $200 \mathrm{mg} \mathrm{mL}^{-1}$, with $100 \%$ worker mortality after the third and fourth days and $100 \%$ soldier mortality by the third through sixth day. Lethal concentrations $\left(\mathrm{LC}_{50}\right)$ varied from 0.624 to $0.710 \mathrm{mg} \mathrm{mL}^{-1}$ for workers and from 0.146 to $1.410 \mathrm{mg} \mathrm{mL}^{-1}$ for soldiers. The extracts were compatible with the fungal strains at the lowest concentrations. Associations of the extracts with $I$. farinosa ESALQ1355 demonstrated efficient control of termite workers. The results demonstrate that $L$. ferrea var. ferrrea extracts, either alone or in association with $I$. farinosa ESALQ1355, functioned in the in vitro control of $N$. corniger, representing a viable alternative to be further tested in controlling those termites in urban areas.
\end{abstract}

Keywords: biological control, entomopathogenic fungi, plant extracts, termites

\section{Introduction}

Nasutitermes corniger (Motschulsky) (Isoptera: Termitidae) is an arboreal termite widely distributed in the Americas, from southern Mexico to northern Argentina. In Brazil, and in most of South America, it is considered one of the most important urban pests, being responsible for enormous damage to structural, decorative, and utilitarian wooden objects. Infestations by that termite have been reported in many Brazilian states with frequent occurrences in the states of Bahia, Pernambuco, Paraíba, Ceará, Pará, and Amazonas, causing serious damage to historic buildings, constructions, and tree trunks, (Milano \& Fontes, 2002; Albuquerque, Matias, Couto, Oliveira, \& Vasconcellos, 2012; Mello, Costa, A. C. Silva, A. M. B. Silva, \& Bezerra-Gusmão, 2014).

Termites have usually been controlled by chemical insecticides, but those compounds are toxic to other living organisms and can cause serious problems in health human and the general environment (Chen, Ohmura, Doi, \& Aovama, 2004). Additionally, those chemical treatments result in the selection for resistant insects that become 
successively more difficult to control (Pourseyed, Tavassoli, Bermousi, \& Mardani, 2010). Entomopathogenic fungi and plant extracts have been shown to be efficient alternatives for controlling insect pests, as they minimize their multiplication and help maintain insect populations in check, but without negatively impacting other organisms or the environment (Marques, Monteiro, \& Pereira, 2004; Lv et al., 2011; Sabbour \& Abdel-Rahman, 2013).

Plants naturally produce bioactive substances, and can serve as potential alternative sources of natural insecticides (Luna et al., 2005; Omena et al., 2007), with many reports in the scientific literature of the in vitro control of $N$. corniger workers and soldiers by plant extracts (Santana et al., 2010; Souza et al, 2011; Lima et al., 2013). Libidibia ferrea (Mart. Ex Tul.) L. P. Queiroz (Fabales: Fabaceae) (= Caesalpinia ferrea) is a widely distributed tree native principally found in northern and northeastern regions of Brazil (Queiroz, 2010), and insecticidal activity has been documented on nymphs and adults of the cochineal Dactylopius opuntiae (Cockerell) (Hemiptera: Dactylopiidae) (Lopes et al., 2018).

Species of Isaria Persoon are known to be efficient in the in vitro control of termites, and certain strains of Isaria fumosorosea (Wize) Brown \& Smith (= Paecilomyces fumosoroseus) and Isaria javanica (Frieder \& Bally) Samson \& Hywell-Jones (= Paecilomyces javanicus) (Hypocreales: Cordycipitaceae) have been patented for controlling the subterranean termites Coptotermes formosanus Shiraki (Isoptera: Rhinotermitidae) and Reticulitermes flavipes (Kollar) (Isoptera: Rhinotermitidae) (Wright, Connick, \& Jackson, 2003). The efficiency in vitro of these fungi was confirmed by C. formosanus, Coptotermes gestroi Wasmann (Isoptera: Rhinotermitidae) and N. corniger (Yanagawa, Yokohari, \& Shimizu, 2008; Lopes, Svedese, Portela, Albuquerque, \& Luna-Alves Lima, 2011; Wright \& Lax, 2013; Passos et al., 2014; Lopes et al., 2017).

The use of entomopathogenic fungi associations with plant oils and extracts could increase their pest control efficacy and (Marques, Monteiro, \& Pereira, 2004; Santos, R. L. S. Oliveira, Costa, Tiago, \& N. T. Oliveira, 2015; Silva, Alves, Luna-Alves Lima, \& Lima, 2015). As such, the present work evaluated the in vitro insecticide potentials of the association of Isaria spp. with the extracts of L. ferrea var. ferrea against $N$. corniger.

\section{Materials and Methods}

The bioassays were carried out at the Biological Control Laboratory of the Agronomic Institute of Pernambuco, Recife, Pernambuco, Brazil ( $\left.8^{\circ} 03^{\prime} 50.2^{\prime \prime} \mathrm{S}, 34^{\circ} 55^{\prime} 29.2^{\prime \prime} \mathrm{W}\right)$.

\subsection{Nasutitermes corniger}

The $N$. corniger termites were collected from nests on the Campus of the Federal University of Pernambuco (UFPE) in Pernambuco State, Brazil $\left(8^{\circ} 03^{\prime} 07^{\prime \prime} \mathrm{S}, 34^{\circ} 56^{\prime} 59^{\prime \prime} \mathrm{W}\right)$. The species was identified in the Biology Department of the Federal Rural University of Pernambuco (UFRPE) by Dr. Auristela Correia de Albuquerque. The adult workers and soldiers could be distinguished and selected based on their physical characteristics (such as body size and color) to standardize the development states of the castes used in the biological tests.

\subsection{Species of Isaria Used in the Experiments}

The I. javanica URM4993, I. farinosa ESALQ1355, and I. fumosorosea ESALQ1297, kept in the URM Culture Collection (WDCM604) of Federal University of Pernambuco (UFPE) and the ESALQ Collection of Microorganisms at "Escola Superior de Agricultura Luiz de Queiroz" (ESALQ) University of São Paulo (USP), were tested for biological activity based on pathogenicity data on $N$. corniger reported by Lopes et al. (2017). The fungal strains were cultivated in Sabouraud medium (SAD) (Peptone-Dextrose-Agar) for 12 days; afterwards, the conidia of each strain were transferred to $10 \mathrm{~mL}$ of Tween $80(0.1 \%)$ solution and quantified using the Neubauer chamber, and the final concentration adjusted at $1 \times 10^{7}$ conidia $\mathrm{mL}^{-1}$. This conidia solution was used for experiments of compatibility with extracts and to obtain $\mathrm{LC}_{50}$ values using $N$. corniger workers, following the procedures in Lopes et al. (2017) (Table 1).

Table 1. Isaria strains used in the experiments

\begin{tabular}{lllll}
\hline Strains & Origin & Host & Gerrmination $(\%)$ & LC $_{50}\left(\mathrm{IC}^{1}\left(\mathrm{conidia}^{\mathrm{mL}}\right)^{1}\right)$ \\
\hline Isaria farinosa ESALQ1355 & ESALQ/Collection & Brassolis sopharea & 91 & $6.66 \times 10^{4}(12.47-3.10)$ \\
Isaria javanica URM4993 & Micoteca/URM & Lonomia obliqua & 98 & $7.22 \times 10^{5}(20.25-2.43)$ \\
Isaria fumosorosea ESALQ1297 & ESALQ/Collection & Bemisia tabaci & 91 & $4.60 \times 10^{5}(13.10-1.38)$ \\
\hline
\end{tabular}

Note. ${ }^{1} 95 \%$ confidence interval.

Source: Lopes et al. (2017). 


\subsection{Obtaining the Plant Extracts}

The leaves and pods of L. ferrea var. ferrea were collected from specimens growing in Euclides da Cunha' Square, Recife, Pernambuco State, Brazil $\left(8^{\circ} 3^{\prime} 30^{\prime \prime} \mathrm{S}, 34^{\circ} 54^{\prime} 12^{\prime \prime} \mathrm{W}\right)$; the specimens were identified at the Botany Department of the Agronomy Institute of Pernambuco/IPA and subsequently deposited in the Dárdano de Andrade Lima Herbarium. The plant material was washed in distilled water to remove any surface impurities, dried at room temperature, and shredded. Aqueous extracts of the leaves and pods of L. ferrea var. ferrea (AELLf and AEPLf) were obtained by mixing $20 \mathrm{~g}$ of the shredded plant material with $80 \mathrm{~mL}$ of a $0.15 \mathrm{M}$ solution of $\mathrm{NaCl}$ to obtain a final concentration of $20 \%(\mathrm{w} / \mathrm{v})$. The suspensions were agitated for $16 \mathrm{~h}$ at $4{ }^{\circ} \mathrm{C}$, filtered, and subsequently centrifuged at $10.000 \mathrm{rpm}$ for $15 \mathrm{~min}$ at $4{ }^{\circ} \mathrm{C}$. Methanol extracts of the leaves and pods (MELLf and MEPLf) were obtained by mixing $20 \mathrm{~g}$ of the shredded material with $80 \mathrm{~mL}$ of methanol. The mixtures were then agitated for $24 \mathrm{~h}$, filtered, and the solvent evaporated in a rotary evaporator. The extracts (200 mg mL $\mathrm{m}^{-1}$ ) were subsequently diluted with distilled water (containing $0.1 \%$ Tween 80 ) to final concentrations of $100 \mathrm{mg} \mathrm{mL}^{-1}, 50 \mathrm{mg} \mathrm{mL}^{-1}, 25 \mathrm{mg} \mathrm{mL}^{-1}$, and $10 \mathrm{mg} \mathrm{mL}^{-1}$ (Lopes et al., 2018).

\subsection{Effects of the Plant Extracts on the Fungal Strains}

The effects of the plant extracts on the fungal strains were determined by evaluating fungal germination, mycelial growth, and sporulation. Each experiment was performed on the three strains of Isaria, employing four extracts (Aqueous-AELLf and AEPLf; Methanol-MELLf and MEPLf) at five different concentrations (10 $\mathrm{mg}$ $\mathrm{mL}^{-1}, 25 \mathrm{mg} \mathrm{mL}^{-1}, 50 \mathrm{mg} \mathrm{mL}^{-1}, 100 \mathrm{mg} \mathrm{mL}^{-1}$, and $200 \mathrm{mg} \mathrm{mL}^{-1}$ ), as well as the control (without extract), with three repetitions, totaling 63 treatments. The conidia of each strain were added to $\mathrm{SAD}$ (liquid, $45^{\circ} \mathrm{C}$ ) and with a solution Tween $80(0.1 \%)$. To evaluate spore germination, $1 \mathrm{~mL}$ of a conidia suspension $\left(1 \times 10^{8}\right.$ conidia $\left.\mathrm{mL}^{-1}\right)$ of each strain was added to $9 \mathrm{~mL}$ of each plant extract concentration, with Tween $80(0.1 \%)$ as the control. After $1 \mathrm{~h}$, we inoculated $0.1 \mathrm{~mL}$ of each suspension separately into Petri dishes containing SAD to be incubated at $26 \pm 1$ ${ }^{\circ} \mathrm{C}$ and $80 \pm 10 \%$ RH. Germination was determined after $16 \mathrm{~h}$ by observing 500 conidia (both germinated and non-germinated), with percentage germination being calculated by the formula: $G=n \times 100 / 500$ (where $G$ is the germination percentage and $\mathrm{n}$ is the number of germinated conidia), according to Alves and Pereira (1998). Evaluations of mycelial growth involve inoculating $0.3 \mathrm{~mm}$ filter paper discs with $0.01 \mathrm{~mL}$ of the conidia suspensions $\left(1 \times 10^{8}\right.$ conidia $\left.\mathrm{mL}^{-1}\right)$ of the different species, which were then placed into Petri dishes with SAD and five concentrations of the plant extracts to be incubated at $26 \pm 1^{\circ} \mathrm{C}$ and $80 \pm 10 \% \mathrm{RH}$ for $12 \mathrm{~d}$. Mycelial growth was quantified by determining colony diameters. To evaluate fungal sporulation, fragments of those colonies were transferred to test tubes containing $10 \mathrm{~mL}$ of Tween $80(0.1 \%)$ solution. The suspensions were then agitated for approximately $2 \mathrm{~min}$ in a Vortex mixer and the conidia were counted using a Neubauer chamber.

\subsection{Efficiencies of the Extracts Against Nasutitermes corniger}

The effects of the extracts on $N$. corniger termites were analyzed following the methodology described by Kang et al. (1990) (modified). Filter paper disks (4 cm diameter) were impregnated with $0.2 \mathrm{~mL}$ of the extracts $(10 \mathrm{mg}$ $\mathrm{mL}^{-1}, 25 \mathrm{mg} \mathrm{mL}^{-1}, 50 \mathrm{mg} \mathrm{mL}^{-1}, 100 \mathrm{mg} \mathrm{mL}^{-1}$, and $200 \mathrm{mg} \mathrm{mL}^{-1}$ ) and Tween $80(0.1 \%)$ solution (control). The impregnated disks were then dried at room temperature and placed in Petri dishes $(90 \times 15 \mathrm{~mm})$ together with a small amount of moistened cotton (to maintain humidity levels) and a fragment of the termite nest (to serve as shelter for the insects). A total of 20 insects (four soldiers and 16 workers) were carefully transferred to the dishes; that pre-established 1:4 ratio is based on the natural interdependence of $N$. corniger casts and helps guarantee the maximum survival of those insects outside their intact nests, according to Vasconcellos and Bandeira (2006). The dishes were maintained at $26 \pm 1{ }^{\circ} \mathrm{C}$, with a relative humidity of $80 \pm 10 \%$ in the absence of light. The experiment included 21 treatments (four extracts $\times$ five concentrations, plus the control) with five repetitions, totaling 100 insects per treatment (20 soldiers and 80 workers). Mortality was evaluated daily until the death of the last insect; those results were used to determine the percentage survival and the Lethal Concentration $\left(\mathrm{LC}_{50}\right)$.

\subsection{Effects of Plant Extracts Associated With Isaria spp. Fungi on Nasutitermes corniger Termites}

The effect of the association of each extract at its $\mathrm{LC}_{50}$ with the fungal extract at $\mathrm{LC}_{50}$ (Tables 1 and 3) was analyzed according to Kang et al. (1990). The paper filter discs (4 cm in diameter) were impregnated separately with $0.2 \mathrm{~mL}$ of the combination of the agents, the extracts, the fungi, and the $0.1 \%$ Tween 80 (control) solution. The impregnated discs were then dried at room temperature and placed in Petri dishes $(90 \times 15 \mathrm{~mm})$ along with a piece of moistened cotton to maintain activity and provide a nest fragment for termite shelter. A total of 16 workers were transferred to each Petri dish, being maintained at $26 \pm 1{ }^{\circ} \mathrm{C}$ and relative humidity of $\pm 80 \%$ and in the dark. These experiments were therefore composed of 21 treatments (four extracts, three strains and 12 
association of the agents, plus the control) with five replications, totaling 100 insects per treatment. The percentage of mortality was evaluated after four days. To confirm the mortality of workers was caused by the fungi, the dead insects were disinfected on the surface in $70 \%$ ethanol and $4 \%$ sodium hypochlorite and rinsed in sterilized distilled water and then kept in a humid chamber $\left(26 \pm 1{ }^{\circ} \mathrm{C}\right.$ and $\left.80 \pm 10 \% \mathrm{RH}\right)$ to be examined for fungal growth.

\subsection{Statistical Analyses}

The level of toxicity of extracts on Isaria spp. was determined by the Biological Index (IB), obtained by means of the formula IB $=47[\mathrm{CV}]+43[\mathrm{ESP}]+10[\mathrm{GERM}] / 100$ (where, $\mathrm{CV}=$ the percentage of vegetative growth; $\mathrm{ESP}=\%$ of sporulation; and GERM $=\%$ conidia germination), all in relation to the control. The IB index may vary from: 0-41 (toxic), 42-66 (moderately toxic) and more than 66 (compatible) according to Rossi-Zalaf, Alves, Lopes, Silveira, Tanzini (2008). The survival rates (\%) were determined for each treatment and the data were submitted to the Log-Rank test, using the Kaplan-Meyer method by pairs of isolates, using the SAS Proc. Lifetest (SAS Institute, 1999-2001). The mean Lethal Concentrations $\left(\mathrm{LC}_{50}\right)$ was determined after the fourth day of treatment, using Proc Probit software (SAS Institute, 1999-2001). Data on mortality of termites caused by the combination of fungi + extracts were submitted to analysis of variance (ANOVA) using the SAS ANOVA Proc (SAS Institute 1999-2001) and the means were compared by the Tukey test at a 5\% level of probability. The control data of the termites are presented graphically using Software GraphPad Prism (Software Prism, 2016).

\section{Results}

Table 2 illustrates the effects of aqueous and methanol extracts of L. ferrea var. ferrea on the biological parameters of the different fungal strains. The aqueous extracts were compatible with the fungal strains at the concentrations tested, except the extract of pods $\left(200 \mathrm{mg} \mathrm{mL}^{-1}\right)$ for I. farinosa ESALQ1355 and leaf extract (200 $\mathrm{mg} \mathrm{mL}^{-1}$ ) for I. javanica URM4993, which were classified as toxic according to the Biological index. In general, the methanolic extracts did not present a fungicidal effect on the strains, being only the extract of pod classified as moderately toxic in the concentrations 100 and $200 \mathrm{mg} \mathrm{mL}^{-1}$ for I. fumosoresea ESALQ1297 and the leaf extract in the concentration $200 \mathrm{mg} \mathrm{mL}^{-1}$ for I. farinosa ESALQ1355, causing significant decreases in the means of mycelia growth and sporulation, mainly.

Table 2. Compatibility of Isaria with extracts of leaves and pod of Libidibia ferrea var. ferrea

\begin{tabular}{|c|c|c|c|c|}
\hline \multirow{2}{*}{ Extract } & \multirow{2}{*}{$\begin{array}{l}\text { Concentration } \\
\left(\mathrm{mg} \mathrm{mL}^{-1}\right)\end{array}$} & \multicolumn{3}{|c|}{ Strains $/^{1}$ IB Values and Classification } \\
\hline & & I. farinosa ESALQ1355 & I. javanica URM4993 & I.fumosorosea ESALQ1297 \\
\hline \multirow{5}{*}{ AEPLf } & 10 & $89.94 \mathrm{C}$ & $92.27 \mathrm{C}$ & $96.25 \mathrm{C}$ \\
\hline & 25 & $82.82 \mathrm{C}$ & $92.27 \mathrm{C}$ & $92.11 \mathrm{C}$ \\
\hline & 50 & $81.63 \mathrm{C}$ & $97.73 \mathrm{C}$ & $92.89 \mathrm{C}$ \\
\hline & 100 & $81.88 \mathrm{C}$ & $97.70 \mathrm{C}$ & $88.05 \mathrm{C}$ \\
\hline & 200 & $44.66 \mathrm{~T}$ & $67.94 \mathrm{C}$ & $72.44 \mathrm{C}$ \\
\hline \multirow{5}{*}{ AELLf } & 10 & $92.38 \mathrm{C}$ & $97.81 \mathrm{C}$ & $94.76 \mathrm{C}$ \\
\hline & 25 & $93.73 \mathrm{C}$ & $92.50 \mathrm{C}$ & $94.06 \mathrm{C}$ \\
\hline & 50 & $86.99 \mathrm{C}$ & $101.95 \mathrm{C}$ & $92.66 \mathrm{C}$ \\
\hline & 100 & $86.99 \mathrm{C}$ & $96.71 \mathrm{C}$ & $89.77 \mathrm{C}$ \\
\hline & 200 & $86.47 \mathrm{C}$ & $40.93 \mathrm{~T}$ & $90.78 \mathrm{C}$ \\
\hline \multirow{5}{*}{ MEPLf } & 10 & $105.90 \mathrm{C}$ & $99.43 \mathrm{C}$ & $81.53 \mathrm{C}$ \\
\hline & 25 & $102.70 \mathrm{C}$ & $98.43 \mathrm{C}$ & $79.95 \mathrm{C}$ \\
\hline & 50 & $101.42 \mathrm{C}$ & $95.78 \mathrm{C}$ & $79.35 \mathrm{C}$ \\
\hline & 100 & $83.28 \mathrm{C}$ & $105.42 \mathrm{C}$ & $60.06 \mathrm{MT}$ \\
\hline & 200 & $42.67 \mathrm{MT}$ & $68.12 \mathrm{C}$ & $45.64 \mathrm{MT}$ \\
\hline \multirow{5}{*}{ MELLf } & 10 & $98.04 \mathrm{C}$ & $97.71 \mathrm{C}$ & $91.51 \mathrm{C}$ \\
\hline & 25 & $96.83 \mathrm{C}$ & $93.92 \mathrm{C}$ & $91.17 \mathrm{C}$ \\
\hline & 50 & $92.59 \mathrm{C}$ & $92.65 \mathrm{C}$ & $115.69 \mathrm{C}$ \\
\hline & 100 & $82.55 \mathrm{C}$ & $101.10 \mathrm{C}$ & $85.07 \mathrm{C}$ \\
\hline & 200 & $49.36 \mathrm{MT}$ & $76.71 \mathrm{C}$ & $85.07 \mathrm{C}$ \\
\hline
\end{tabular}

Note. ${ }^{1}$ Biological Index: C compatible (above 66), MT moderately toxic (42-66), T toxic (0-41).

The survival of $N$. corniger treated with aqueous extracts of L. ferrea var. ferrea was shown in (Figure 1). The 
extracts presented significant insecticidal activity in vitro against $N$. corniger, reducing termite survival in relation to control treatments, which showed a life time of up to 11 days. Survival tests have reported that the aqueous extracts of L. ferrea var. ferrea were more effective causing death of termites in a lower time (3 to 5 days) than the pod extracts treatments. Differences in daily survival between the control group and the treatments reinforce the findings on insecticidal effect of aqueous extracts.

The AELLf treatment was the most effective, causing complete termite death in three days at concentrations of $50 \mathrm{mg} \mathrm{mL}^{-1}\left(\mathrm{LC}_{50}=0.624 \mathrm{mg} \mathrm{mL}^{-1}\right)$ among both workers (Figure 1a; Table 3$)$ and soldiers $\left(\mathrm{LC}_{50}=0.146 \mathrm{mg}\right.$ $\mathrm{mL}^{-1}$ ) (Figure 1b; Table. 3); the other concentrations resulted in insects survival until the fifth day. The AEPLf treatment resulted in the death of $100 \%$ of the insects by the fourth day of exposure at a concentration of $100 \mathrm{mg}$ $\mathrm{mL}^{-1}\left(\mathrm{LC}_{50}\right.$ of $0.710 \mathrm{mg} \mathrm{mL}^{-1}$ ) (Figure 1c; Table 3), promoting the death of $100 \%$ of the workers (Figure 1c) by the third day $\left(200 \mathrm{mg} \mathrm{mL}^{-1}\right)$ and $100 \%$ of the soldiers by the fourth day with the concentration of $50 \mathrm{mg} \mathrm{mL}^{-1}$ $\left(\mathrm{LC}_{50}=1.410 \mathrm{mg} \mathrm{mL}^{-1}\right)$ (Figure 1d; Table 3).
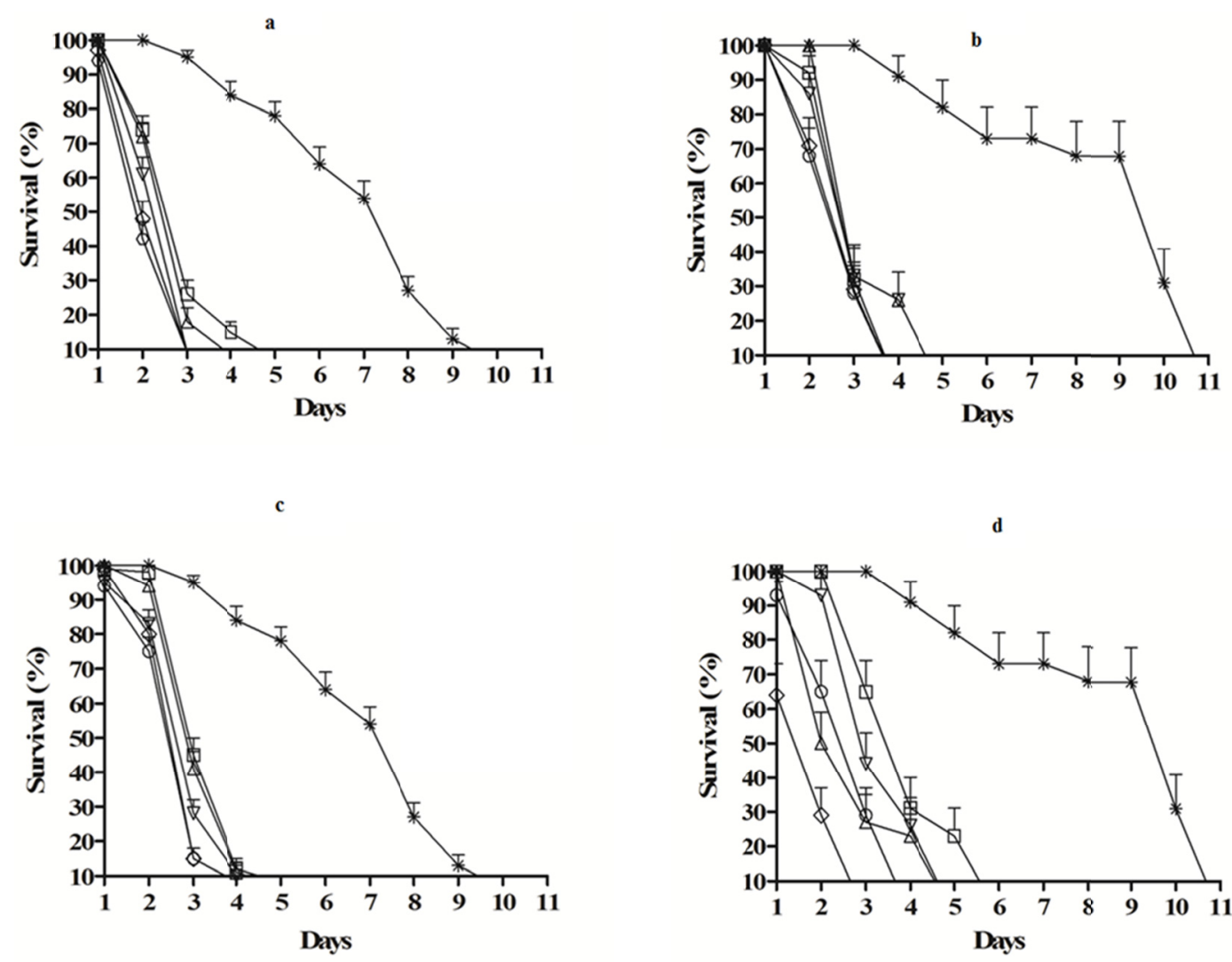

Figure 1. Daily survival (\%) of workers and soldiers of Nasutitermes corniger treated with aqueous extracts of Libidibia ferrea var. ferrea evaluated until death of the last individual by the Log-Rank test: AELLf effects on workers (a) and soldiers (b). AEPLf effects on workers (c) and soldiers (d), at concentrations of $10(\square), 25(\triangle)$, $50(\nabla), 100(\diamond), 200 \mathrm{mg} / \mathrm{mL}(\diamond)$, and the control $(*)$. Each point represents the mean \pm SE of five repetitions

Table 3. Lethal concentrations $\left(\mathrm{LC}_{50}\right)$ of Libidia. ferrea var. ferrea on Nasutitermes corniger

\begin{tabular}{|c|c|c|c|c|c|c|}
\hline \multirow{2}{*}{ Extracts } & \multicolumn{3}{|c|}{ Workers } & \multicolumn{3}{|c|}{ Soldiers } \\
\hline & $\mathrm{LC}_{50}(\mathrm{IC})^{1}\left(\mathrm{mg} \mathrm{mL}^{-1}\right)$ & Regression equation & $\left(\chi^{2}\right)^{2}$ & $\mathrm{LC}_{50}(\mathrm{IC})\left(\mathrm{mg} \mathrm{mL}^{-1}\right)$ & Regression equation & $\left(\chi^{2}\right)$ \\
\hline AEPLf & $0.710(1.163-0.297)$ & $\mathrm{Y}=5.14954+1.00908 * \log X$ & 28.40 & $1.410(2.098-0.698)$ & $\mathrm{Y}=4.71308+1.92107 * \log X$ & 29.05 \\
\hline AELLf & $0.624(0.844-0.363)$ & $Y=5.49411+2.41777 * \log X$ & 57.12 & $0.146(0.657-0.00)$ & $\mathrm{Y}=5.9102+1.09267 * \log \mathrm{X}$ & 77.36 \\
\hline MEPLf & $0.255(1.116-0.000)$ & $\mathrm{Y}=5.19769+0.033384 * \log$ & 62.02 & $2.871(4.092-1.815)$ & $Y=4.15853+1.8367 * \log X$ & 25.34 \\
\hline MELLf & $1.279(2.978-0.021)$ & $Y=4.96053+0.36901 * \log X$ & 75.57 & $8.003(23.465-4.365)$ & $\mathrm{Y}=4.10687+0.98879 * \log \mathrm{X}$ & 21.65 \\
\hline
\end{tabular}

Note. ${ }^{1} 95 \%$ confidence interval. ${ }^{2}$ Significant analyses $(\mathrm{p}=0.05)$ by the Chi-square test. 
The MELLf treatment caused the death of $100 \%$ of the workers and soldiers by the seventh day at $200 \mathrm{mg} \mathrm{mL}^{-1}$ concentration (Figure 2a). Similarly, other concentrations of that extract $\left(50\right.$ and $\left.100 \mathrm{mg} \mathrm{mL}^{-1}\right)$ caused the death of $100 \%$ of the workers after the ninth day while soldiers survived between 7 and $8 \mathrm{~d}\left(50,100\right.$ and $\left.200 \mathrm{mg} \mathrm{mL}^{-1}\right)$ (Figure 2b). MEPLf extracts (100 and $200 \mathrm{mg} \mathrm{mL}^{-1}$ ) caused the death of $100 \%$ of the workers after eight days, while the other concentrations caused the deaths of all of the workers between the ninth and 10th day (Figure 2c), with $100 \%$ of the soldiers dying after the eight day (100 and $\left.200 \mathrm{mg} \mathrm{mL}^{-1}\right)$; exposure to the other concentrations allowed soldiers to survive between nine and $11 \mathrm{~d}\left(10,25,50 \mathrm{mg} \mathrm{mL}^{-1}\right)$, (Figure 2d). The LC 50 values of MELLf and MEPLf were $1.279 \mathrm{mg} \mathrm{mL}^{-1}$ and $0.255 \mathrm{mg} \mathrm{mL}^{-1}$ for workers, and $2.871 \mathrm{mg} \mathrm{mL}^{-1}$ and $8.003 \mathrm{mg} / \mathrm{mL} \mathrm{for}^{2}$ soldiers respectively (Table 3 ).
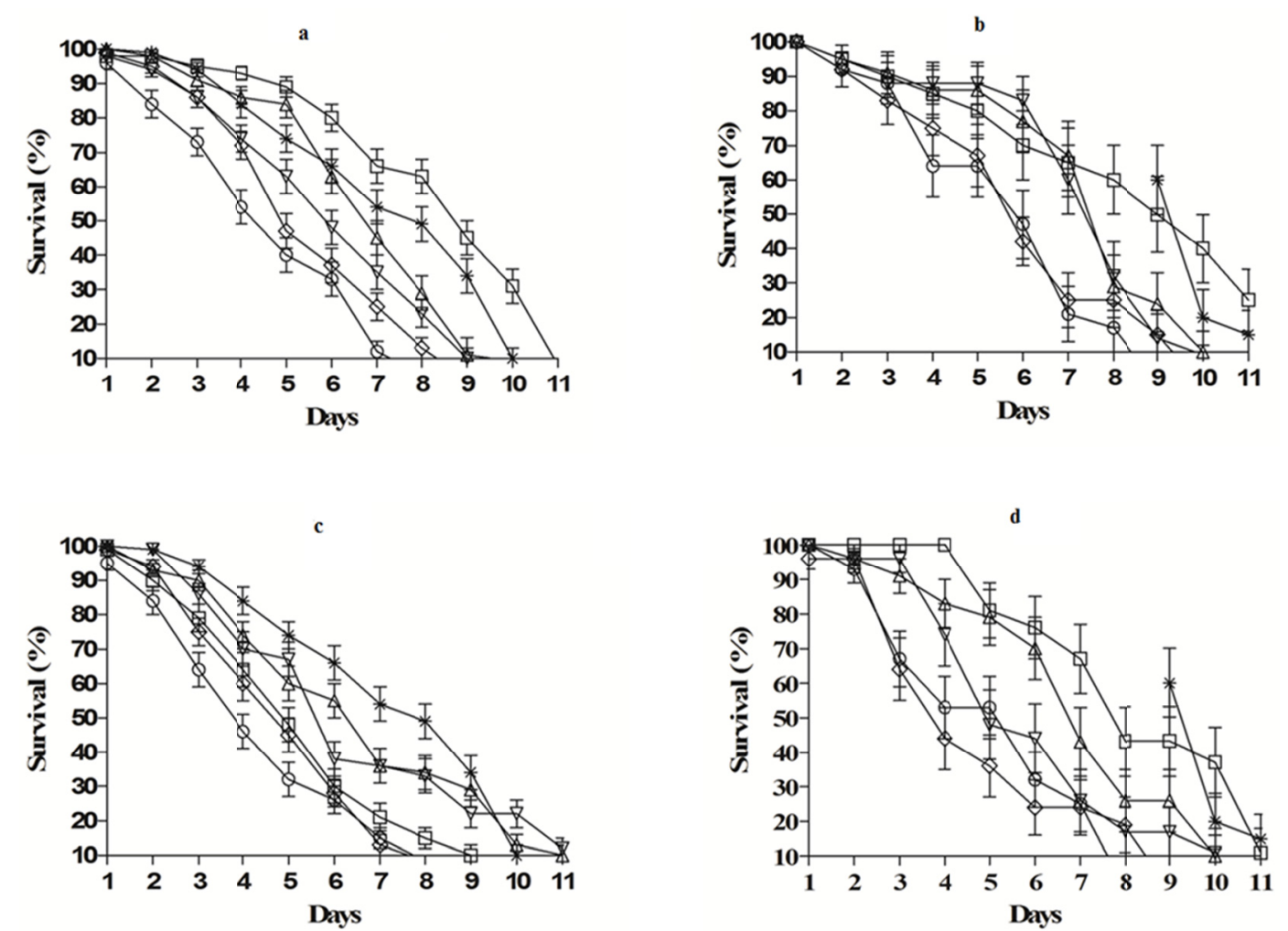

Fiure 2. Daily survival (\%) of workers and soldiers of Nasutitermes corniger treated with methanol extracts of Libidibia ferrea var. ferrea evaluated until death of the last individual by the Log-Rank test: MELLf effects on workers (a) and soldiers (b). MEPLf effects on workers (c) and soldiers (d), at concentrations of $10(\square), 25(\triangle)$, $50(\nabla), 10 \theta(\diamond), 200 \mathrm{mg} / \mathrm{mL}(\ominus)$ and the control $(*)$. Each point represents the mean \pm SE of five repetitions

Figures 3 and 4 illustrate the in vitro effects of associations of extracts with fungal strains on mortality of $N$. corniger workers. Associations of the AELLf and AEPLf extracts with I. farinosa ESALQ1355 (Figure 3a; Figure 4a) were effective in causing an increase in mortality, causing the death of $70 \%$ more workers as compared to the extracts and fungal strains used alone $(\mathrm{p}=0.05)$. Associations of the plant extracts with I. javanica URM4993 (Figure 3b; Figure 4b) and I. fumosorosea ESALQ1297 (Figure 3c; Figure 4c) did not demonstrate synergistic effects against $N$. corniger, as no significant statistical differences were observed between the percent mortalities of the termites in the fungus+extract associations and their isolated applications $(\mathrm{p}=0.05)$. 


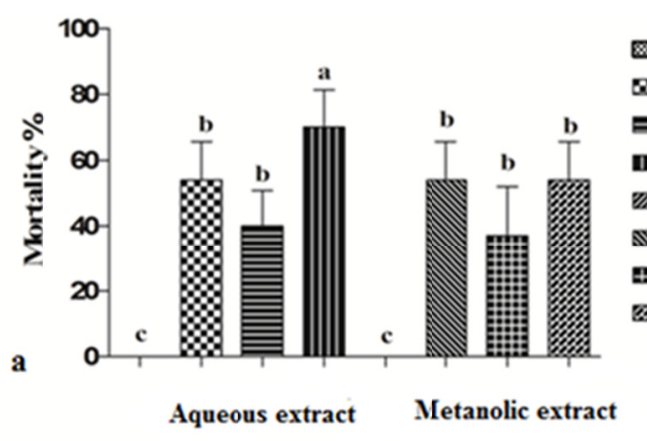

Control

$\$ \infty$ I. farinosa ESALQ1355

= Aqueous extract

III Association

שnמ Control

MIV I. farinosa ESALQ1355

III Metanolic extract

232 Association

b

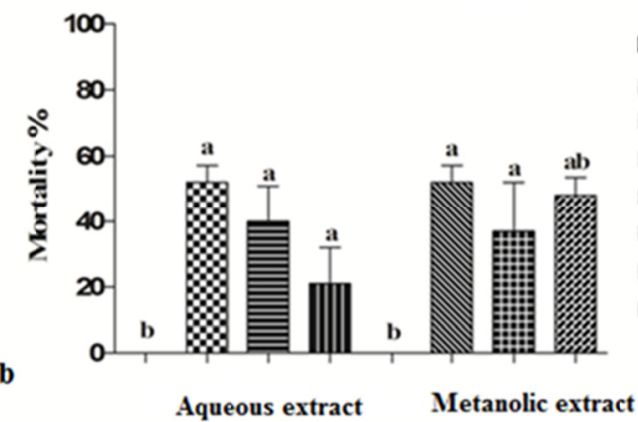

Control

$\infty$ I. javanica URM4993

= Aqueous extract

III Association

man Control

बII I. javanica URM4993

III Metanolic extract

ass Association

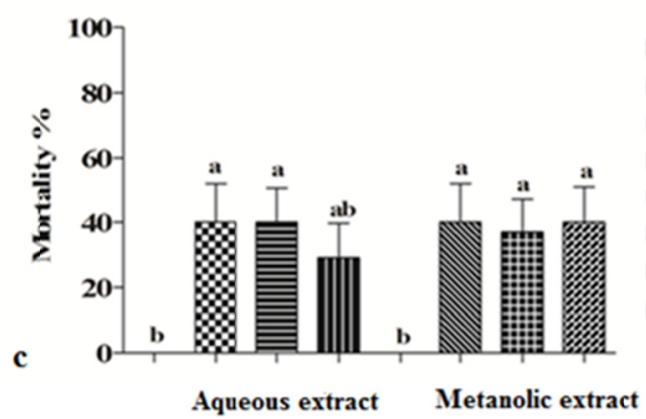

Control

00 L. fumosorosea ESALQ1297

$=$ Aqueous extract

III Association

em Control

@W L fumosorosea ESALQ1297

III Metanolic extract

ess Association

Figure 3. Effects of the associations of fungal strains with aqueous and methanol extracts of the leaves of Libidibia ferrea var. ferrea against Nasutitermes corniger workers: Isaria farinosa ESALQ1355 (a), Isaria javanica URM4993 (b), and Isaria fumosorosea ESALQ1297 (c). Different letters in the bars indicate statistically significant differences 


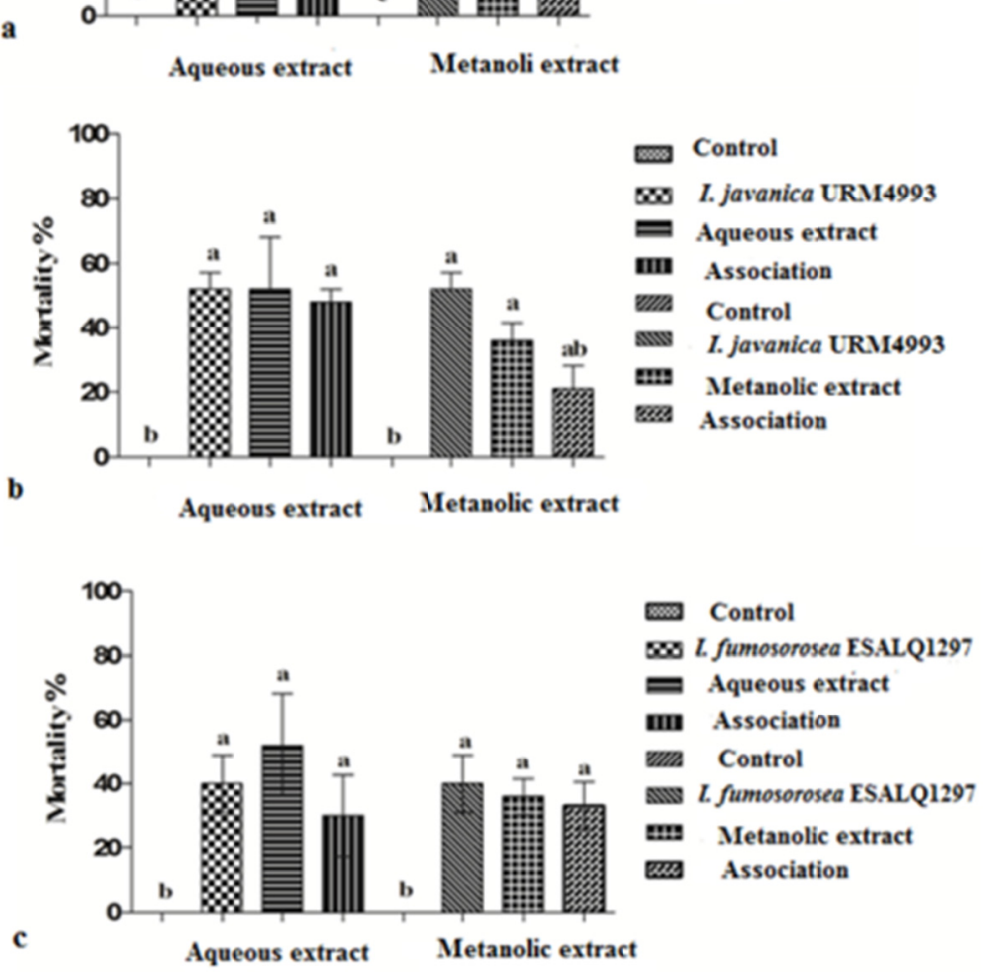

Figure 4. Effects of the associations of fungal strains with aqueous and methanol extracts of the pods of Libidibia ferrea var. ferrea against Nasutitermes corniger workers: Isaria farinosa ESALQ1355 (a), Isaria javanica URM4993 (b), and Isaria fumosorosea ESALQ1297 (c). Different letters in the bars indicate statistically significant differences between them by the Tukey test $(\mathrm{p}=0.05)$

\section{Discussion}

The extracts were compatible with the fungi, except in concentrations of 100 and $200 \mathrm{mg} \mathrm{mL}^{-1}$, in general, were classified as moderately toxic to toxic, and caused decrease in growth and fungal sporulation. The effect of biological products on Isaria spp. was analyzed. Marques, Monteiro, and Pereira (2004) observed that neem oil reduced mycelial growth and sporulation but did not affect the germination of I. farinosa. Matsuura and Matsunaga (2015) reported that the fungicidal pheromones ethylene n-butyl-n-butyrate and 2-methyl-1-butanol, extracted from the termite queens of Reticulitermes speratus (Kolbe) (Isoptera: Rhinotermitidae) significantly reduced conidia germination, growth, and sporulation of I. farinosa. However, Xu, Ali, and Huang (2011) verified that the secondary metabolic compound 20-Hydroxyecdysone did not have any negative effect on germination, mycelial growth and the production of conidia of I. fumosorosea.

Our data demonstrated the insecticidal efficiency of the L. ferrea var. ferrea extracts, on N. corniger workers and soldiers, under laboratory conditions. Plants demonstrating resistance to termite attacks are being considered potential alternative sources of natural insecticides, and their bioactive compounds are less damaging to humans and the natural environment than industrial chemicals (Luna et al., 2005; Omena et al., 2007).

The insecticidal actions of the extracts AELLf and AEPLf on $N$. corniger workers and soldiers were greater than those of the MELLf and MEPLf extracts, because they caused the death of the insect in shorter times of survival and with lower values of $\mathrm{LC}_{50}$, with the extract of AELLf considered the most insecticidal. Similarly, Santana et al. (2010) reported that $N$. corniger survived only to the fourth day when treated with extracts of Bowdichia 
virgilioides Kunth (Fabales: Fabaceae) at a concentration of $100 \mathrm{mg} \mathrm{mL} \mathrm{L}^{-1}\left(\mathrm{LC}_{50} 7.2 \mathrm{mg} \mathrm{mL}^{-1}\right.$ ), while ethyl acetate extracts of Anadenanthera colubrina (Vell.) Brenan (Fabales: Fabaceae) at concentrations of $25 \mathrm{mg} \mathrm{mL}^{-1}$, $50 \mathrm{mg} \mathrm{mL}^{-1}$, and $100 \mathrm{mg} \mathrm{mL}^{-1}\left(\mathrm{LC}_{50} 17.3 \mathrm{mg} \mathrm{mL}^{-1}\right)$ occasioned the death of $100 \%$ of the insects by the seventh day of treatment. Likewise, Soares, Lemos, Cardoso, Medeiros, and Araújo (2008) tested the effects of neem (Azadirachta indica A. Juss.) (Sapindales: Meliaceae) and citronella (Cymbopogon winterianus Jowitt) (Poales: Poaceae) extracts at concentrations of $1 \mathrm{mg} \mathrm{mL}^{-1}, 5 \mathrm{mg} \mathrm{mL}^{-1}$, and $10 \mathrm{mg} \mathrm{mL}^{-1}$ against $N$. corniger and reported that the neem extract was the most efficient, with higher mortality by the third day of treatment. Araújo et al. (2012) demonstrated that a lectin isolated from Crataeva tapia L. (Brassicales: Capparaceae) was effective against $N$. corniger, causing the death of all of those insects after six days $\left(\mathrm{LC}_{50}=0.475 \mathrm{mg} \mathrm{mL}^{-1}\right)$.

Possibly, the insecticidal activity of the tested extracts of $L$. ferrea var. ferrea on $N$. corniger may be related to the toxicity of their primary and secondary chemical compounds. Previous studies of the extracts of the leaves, stems, and bark of $L$. ferrea var. ferrea reported the presence of flavonoids, saponins, tannins, gallic acid, coumarins, steroids, and phenolic compounds (Wyrepkowski et al., 2014). Bioactive compounds such as alkaloids, tannins, terpenoids, glycosides, phenolics, and phenylpropanoids can have attractive, deterrent, and insecticidal properties (Cheng, Chang, Wu, \& Chang, 2007; Melo-Santos, Araújo, Rios, \& Regis, 2009). Primary metabolites such as lectins have been tested for controlling $N$. corniger in the laboratory, with the lectins extracted from Myracrodruon urundeuva Fr. (Sapindales: Anacardiaceae) causing 100\% mortality among workers $\left(\mathrm{LC}_{50}=0.374 \mathrm{mg} \mathrm{mL}^{-1}\right.$ and $\left.0.974 \mathrm{mg} \mathrm{mL}^{-1}\right)$ and soldiers $\left(\mathrm{LC}_{50}=0.432 \mathrm{mg} \mathrm{mL}^{-1}\right.$ and $\left.0.787 \mathrm{mg} \mathrm{mL}^{-1}\right)$ (Napoleão et al., 2011). Similarly, a lectin extracted from Bauhinia monandra Kurz (Fabales: Fabaceae) demonstrated termiticide activity against workers and soldiers of an arboreal termite after the 12th day of exposure $\left(\mathrm{LC}_{50}=0.09 \mathrm{mg} \mathrm{mL}^{-1}\right.$ and $0.395 \mathrm{mg} \mathrm{mL}^{-1}$ respectively), demonstrating its biotechnological potential for controlling termite-pests (Souza et al., 2011). The greater observed efficiencies of aqueous extracts of $L$. ferrea var. ferrea in comparison to methanol extracts in controlling $N$. corniger are related to the different primary and secondary compounds encountered in those extracts, as well as their quantities, although our data indicates that both types of extracts contain toxic or anti-feeding compounds that affect both workers and soldiers.

The most important steps in selecting an entomopathogenic fungus for potential use as a bioinsecticide include determining its virulence, reproductive aspects, and production when grown in artificial medium (Ambethgar, 2009; Lopes, Svedese, Portela, Albuquerque, \& Luna-Alves Lima, 2011). The effects of pathogens can often be increased when associated with plant extracts - although it will always be necessary to determine what extract concentrations are compatible with the fungus itself.

The associations of the extracts AELLf and AEPLf with I. farinosa ESALQ1355 may have increased the fungus capacity to infect termites, making it more pathogenic, which suggests a synergistic action of the agents in the control of $N$. corniger. Termites live and work in varied environments that could make them susceptible to infections and to the rapid transmission of illnesses - thus favoring pathogen propagation. On the other hand, the initiation and epizootic spread of diseases within the termite nest could be slowed by inherent defense mechanisms (mechanical and/or chemical) such as their excretion of chemicals against entomopathogenic fungi (Chouvenc, Su, \& Kenneth, 2011; Hamilton, Lay, \& Bulmer, 2011). The use of plant extracts in association with I. farinosa ESALQ1355 may have stressed those termites and facilitated the penetration of the fungal conidia into tegument. As such, associations of entomopathogenic fungi with chemical insecticides or plant extracts can amplify their effects against insect pests while diminishing environmental damage (Amjad, Bashir, Afzal, Sabri, \& Javed, 2012; Silva, Alves, Luna-Alves Lima, \& Lima, 2015). The increased potential for fungal control of $N$. corniger observed when I. farinosa ESALQ1355 was associated with aqueous extracts of $L$. ferrea var. ferrea therefore corroborates previous reports in the literature of associations of agents in insect control.

Integrated insect control, combining entomopathogenic fungi and chemical control products such as insecticides or plant extracts, takes advantage of their synergetic interactions - so that low doses of those products can be effectively used against insect pests while preserving their natural enemies, decreasing environmental pollution, and decreasing the risk of selecting for resistant insects (Marques, Monteiro, \& Pereira, 2004; Ambethgar, 2009). Previous studies report the synergism of the interaction between entomopathogenic fungi and bioactive products in the control of insect pests. In this sense, Xu, Ali, and Huang (2011) demonstrated that the mortality of Plutella xylostella L. (Lepidoptera: Plutellidae) caused by the fungus I. fumosorosea when associated with different concentrations of 20-hydroxyecdysone was directly related to the concentrations of each component in the solution, and that cumulative effects were observed with greater exposure times. Similarly, Santos, Oliveira, Costa, Tiago, and Oliveira (2015) examined the insecticidal action of extracts (aqueous and hydro-ethanolic) of $R$. communis and P. pyramidalis applied together with the fungus $F$. incarnatum-equiseti against $D$. opuntiae, and 
found the greatest efficiency to be the association of the fungus with the aqueous extract of $R$. communis-with $100 \%$ mortality of $D$. opuntiae females.

\section{Conclusion}

The termite, $N$. corniger, is a serious pest in urban areas throughout the world, and efficient but environmentally friendly methods of controlling them are desperately needed, while diminishing the use of chemical insecticides. Our results demonstrated the in vitro termiticide actions of extracts of $L$. ferrea var. ferrea against $N$. corniger soldiers and workers, and the potential efficiency of the association of AELLf or AEPLf with the fungus, $I$. farinosa ESALQ1355, against termite workers. As such, those agents appear to be viable options for continued testing for controlling $N$. corniger in urban areas.

\section{References}

Albuquerque, A. C., Matias, G. R. R. S., Couto, A. V. O., Oliveira, M. A. P., \& Vasconcellos, A. (2012). Urban termites of Recife, northeast Brazil (Isoptera). Sociobiology, 59(1), 183-188. https://doi.org/10.13102/ sociobiology.v59i1.675

Alves, S. B., \& Pereira R. M. (1998). Produção de fungos entomopatogênicos. In S. B. Alves (Ed.), Controle Microbiano de Insetos (2nd ed., pp. 845-867). Piracicaba: FEALQ.

Ambethgar, V. (2009). Potential of entomopathogenic fungi in insecticide resistance management (IRM): A review. Journal of Biopesticides, 2(2), 177-193.

Amjad, M., Bashir, M. H., Afzal, M., Sabri, M. A., \& Javed, N. (2012). Effects of commercial pesticides against cotton whitefly (Bemisia tabaci Genn.) and mites (Tetranychus urticae Koch) on growth and conidial germination of two species of entomopathogenic fungi. Pakistan Journal of Life and Social Sciences, 10(1), 22-27. Retrieved from http://www.pjlss.edu.pk/pdf_files/2012_1/22-27.pdf

Araújo, R. M. S., Ferreira, R. S., Napoleão, T. H., Cunha, M. G. C., Coelho, C. B. B., Correia, M. T. S., ... Paiva P. M. G. (2012). Crataeva tapia bark lectin is an affinity adsorbent and insecticidal agent. Plant Science, 183(4), 20-26. https://doi.org/10.1016/j.plantsci.2011.10.018

Chen, K., Ohmura, W., Doi, S., \& Aoyama, M. (2004). Termite feeding deterrent from Japanese Larch wood. Bioresource Technology, 95(2), 129-134. https://doi.org/10.1016/j.biortech.2004.02.014

Cheng, S. S., Chang, H. T., Wu, C. L., \& Chang, S. T. (2007). Anti-termitic activities of essential oils from coniferous trees against Coptotermes formosanus. Bioresource Technology, 98(2), 456-459. https://doi.org/ 10.1016/j.biortech.2006.01.006

Chouvenc, T., Su, N. Y., \& Kenneth, G. J. (2011). Fifty years of attempted biological control of termites-Analysis of a failure. Biological Control, 59(2), 69-82. https://doi.org/10.1016/j.biocontrol. 2011.06.015

Hamilton, C., Lay, F., \& Bulmer, M. S. (2011). Subterranean termite prophylactic secretions and external antifungal defenses. Journal of Insect Physiology, 57(9), 1259-1266. https://doi.org/10.1016/j.jinsphys. 2011.05.016

Kang, H. Y., Matsushima, N., Sameshima, K., \& Takamura, N. (1990). Termite resistance tests of hardwoods of Kochi growth. The strong termiticidal activity of kagonoki (Litsea coreana Léveillé). Mokuzai Gakkaishi, 36(1), 78-84. Retrieved from https://eurekamag.com/research/002/240/002240536.php

Lima, J. K. A., Albuquerque, E. L. D., Santos, A. C. C., Oliveira, A. P., Araújo, A. P. A., Blank, A. F., ... Bacci, L. (2013). Biotoxicity of some plant essential oils against the termite Nasutitermes corniger (Isoptera: Termitidae). Industrial Crops and Products, 47, 246-251. https://doi.org/10.1016/j.indcrop.2013.03.018

Lopes, R. S., Svedese, V. M., Portela, A. P. A. S., Albuquerque, A. C., \& Luna-Alves Lima, E. A. (2011). Virulence and biological aspects of Isaria javanica (Frieder \& Bally) Samson \& Hywell-Jones in Coptotermes gestroi (Wasmann) (Isoptera: Rhinotermitidae). Arquivos do Instituto Biológico, 78(4), 565-572. Retrieved from http://www.biologico.sp.gov.br/uploads/docs/arq/v78_4/lopes1.pdf

Lopes, R. S., Lima, G., Correia, M. T. S., Costa, A. F., Luna-Alves Lima, E. A., \& Lima, V. L. M. (2017). The potential of Isaria spp. as a bioinsecticide for the biological control of Nasutitermes corniger. Biocontrol Science and Technology, 27(9), 1038-1048. https://doi.org/10.1080/09583157.2017.1380163

Lopes, R. S., Oliveira, L. G., Costa, A. F., Correia, M. T., Luna-Alves Lima, E. A., ... Lima, V. L. M. (2018). Efficacy of Libidibia ferrea var. ferrea and Agave sisalana extracts against Dactylopius opuntiae (Hemiptera: Coccoidea). Journal of Agricultural Science, 10(4), 255-267. https://doi.org/10.5539/ 
jas.v10n4p255

Luna, J. S., Santos, A. F., Lima, M. R. F., Omena, M. C., Mendonça, F. A. C., Bieber, L. W., ... Sant'Ana, A. E. G. (2005). A study of the larvicidal and molluscicidal activities of some medicinal plants from Northeast Brazil. Journal of Ethnopharmacology, 97(2), 199-206. https://doi.org/10.1016/j.jep.2004.10.004

Lv, J., Wilson, L. T., Beuzelin, J. M., White, W. H., Reagan, T. E., ... Way, M. O. (2011). Impact of Cotesia flavipes (Hymenoptera: Braconidae) as an augmentative biocontrol agent for the sugarcane borer (Lepidoptera: Crambidae) on rice. Biological Control, 56(2), 159-169. https://doi.org/10.1016/j.biocontrol. 2010.10.005

Marques, R. P., Monteiro, A. C., \& Pereira, G. T. (2004). Crescimento, esporulação e viabilidade de fungos entomopatogênicos em meios contendo diferentes concentrações do óleo Nim (Azadirachta indica). Ciência Rural, 34(6), 1675-1689. https://doi.org/10.1590/S0103-84782004000600002

Matsuura, K., \& Matsunaga, T. (2015). Antifungal activity of a termite queen pheromone against egg-mimicking termite ball fungi. Ecological Research, 30(1), 93-100. https://doi.org/10.1007/s11284-014-1213-7

Melo-Santos, M. A. V., Araújo, A. P., Rios, E. M. M., \& Regis, L. (2009). Long lasting persistence of Bacillus thuingiensis larvicidal serovar. israelensis activity in Aedes aegypti (Diptera: Culicidae) breeding places is associated to bacteria recycling. Biological Control, 49(2), 186-191. https://doi.org/10.1016/j.biocontrol. 2009.01.011

Mello, A. P., Costa, B. G., Silva, A. C., Silva, A. M. B., \& Bezerra-Gusmão, M. A. (2014). Termite infestation in historical buildings and residences in the semiarid region of Brazil. Sociobiology, 61(3), 318-323, https://doi.org/10.13102/sociobiology.v61i3.318-323

Milano, S. E., \& Fontes, L. R. (2002). Termite pests and their control in urban Brazil. Sociobiology, 40(1), 163-177.

Napoleão, T. H., Gomes, F. S., Lima, T. A., Santos, N. D. L., Sá, R. A., Albuquerque, A. C., ... Paiva, P. M. G. (2011). Termiticidal activity of lectins from Myracrodruon urundeuva against Nasutitermes corniger and its mechanisms. International Biodeterioration \& Biodegradation, 65(1), 52-59. https://doi.org/10.1016/j.ibiod. 2010.05.015

Omena, M. C., Navarro, D. M. A. F., Paula, J. E., Luna, J. S., Lima, M. R. F, ... Santana, A. E. G. (2007). Larvicidal activities agaisnst Aedes aegypti of some Brazilian medicinal plants. Bioresoure Technology, 98(13), 2549-2556. https://doi.org/10.1016/j.biortech.2006.09.040

Passos, E. M., Albuquerque, A. C., Marques, E. J., Teixeira, V. W., Silva, C. C. M., \& Oliveira, M. A. P. (2014). Effects of Isaria (Persoon) isolates on the subterranean termite Coptotermes gestroi (Wasmann) (Isoptera: Rhinotermitidae). Arquivos do Instituto Biológico, 81(3), 232-237. https://doi.org/10.1590/1808-165700 0642012

Pourseyed, S. H., Tavassoli, M., Bermousi, I., \& Mardani, K. (2010). Metarhizium anisopliae (Ascomycota: Hypocreales): An effective alternative to chemical acaricides against different developmental stages of fowl tick Argas persicus (Acari: Argasidae). Veterinary Parasitology, 172(3-4), 305-310. https://doi.org/10.1016/ j.vetpar.2010.05.014

Queiroz, L. P. (2010). New combinations in Libidibia (DC.) Schltdl., and Poiciaella Britto \& Rose (Leguminosae, Caesalpinioideae). Neodiversity, 5(1), 11-12. https://doi.org/10.13102/neod.51.3

Rossi-Zalaf, L. S., Alves, S. B., Lopes, R. B., Silveira, N. S., \& Tanzini, M. R. (2008). Interação de microrganismos com outros agentes de controle de pragas e doenças. In S. B. Alves, \& R. B. Lopes (Eds.), Controle Microbiano de Pragas na América latina: Avanços e Desafios (pp. 279-302). Piracicaba: FEALQ.

Sabbour, M. M., \& Abdel-Rahman, A. (2013). Efficacy of isolated Nomuraea rileyi and Spinosad against corn pests under laboratory and field conditions in Egypt. Annual Review \& Research in Biology, 3(4), 903-912. Retrieved from http://www.journalarrb.com/index.php/ARRB/article/view/24952/46672

Santana, A. L. B. D., Maranhão, C. A., Santos, J. C., Cunha, F. M., Conceição, G. M., Bieber, L. W., ... Nascimento, M. S. (2010). Antitermitic activity of extractives from three Brazilian hardwoods against Nasutitermes corniger. International Biodeterioration and Biodegradation, 64(1), 7-12. https://doi.org/ 10.1016/j.ibiod.2009.07.009

Santos, A. C. S., Oliveira, R. L. S., Costa, A. F., Tiago, P. V., \& Oliveira, N. T. (2015). Controlling Dactylopius opuntiae with Fusarium incarnatum-equiseti species complex and extracts of Ricinus communis and 
Poincianella pyramidalis. Journal of Pest Science, 8(2), 1-9. https://doi.org/10.1007/s10340-015-0689-4

Sas Institute. (1999-2001). SAS user's guide: Statistics (6th ed., Version 8.2). Cary, NC: SAS Institute.

Silva, A. P. A. P., Alves, R. T., Luna-Alves, Lima, E. A., \& Lima, V. L. M. (2015). Bioformulations in Pest Control-A Review. Annual Research \& Review in Biology, 5(6), 535-543. https://doi.org/10.9734/ ARRB/2015/12395

Soares, C. G., Lemos, R. N. S., Cardoso, S. R. S., Medeiros, F. R., \& Araújo, J. R. G. (2008). Efeito de óleos e extratos aquosos de Azadirachta indica A. Juss e Cymbopogon winterianus Jowitt sobre Nasutitermes corniger Motschulsk (Isoptera: Termitidae). Revista de Ciências Agrárias, 50(2), 107-116.

Software Prism. (2016). Software Prism, Version 6.0. La Jolla, California, USA.

Souza, J. D., Silva, M. B. R, Argolo, A. C. C., Napoleão, T. H., Sá, R. A., Correia, M. T. S., ... Coelho, L. C. B. B. (2011). A new Bauhinia monandra galactose-specific lectin purified in milligram quantities from secondary roots with antifungal and termiticidal activities. International Biodeterioration \& Biodegradation 65(5), 696-702. https://doi.org/10.1016/j.ibiod.2011.02.009

Vasconcellos, A., \& Bandeira, A. G. (2006). Populational and reproductive status of a polycalic colony of Nasutitermes corniger (Isoptera, Termitidae) in the urban area of João Pessoa, NE Brazil. Sociobiology, 47(1), 165-174.

Wright, M. S., Connick, W. J., \& Jackson, M. A. (2003). Use of Paecilomyces spp. as pathogenic agents against subterranean termites (U.S. Patent No. 6.660.291B2). Washington, DC: Secretary of Agriculture.

Wright, M., \& Lax, A. (2013). Combined effect of microbial and chemical control agents on subterranean termites. Journal of Microbiology, 51(5), 578-58. https://doi.org/10.1007/s12275-013-2628-5

Wyrepkowski, C. C., Costa, D. L. M. G., Sinhorin, A. P., Vilegas, W., Grandis, R. A., Resende, F. A., ... Santos, L. C. (2014). Characterization and quantification of the compounds of the ethanolic extract from Caesalpinia ferrea Stem Bark and evaluation of their mutagenic activity. Molecules, 19(10), 16039-16057. https://doi.org/10.3390/molecules191016039

Xu, D., Ali, S., \& Huang, Z. (2011). Insecticidal activity influence of 20-Hydroxyecdysone on the pathogenicity of Isaria fumosorosea against Plutella xylostella. Biological Control, 56(3), 239-244. https://doi.org/ 10.1016/j.biocontrol.2010.11.011

Yanagawa, A., Yokohari, F., \& Shimizu, S. (2008). Defense mechanism of the termite, Coptotermes formosanus Shiraki, to entomopathogenic fungi. Journal Invertebrate Pathology, 97(2), 165-170. https://doi.org/ 10.1016/j.jip.2007.09.005

\section{Copyrights}

Copyright for this article is retained by the author(s), with first publication rights granted to the journal.

This is an open-access article distributed under the terms and conditions of the Creative Commons Attribution license (http://creativecommons.org/licenses/by/4.0/). 